\section{Papel modulador do estradiol sobre os transtornos psíquicos}

O trabalho dos colegas Bassit e Louzã Neto ${ }^{1}$ aborda um tema que desperta grande interesse, embora ainda pouco explorado em pesquisas brasileiras: a modulação dos quadros psíquicos pelos hormônios sexuais e suas repercussões clínicas. Os autores destacam a relação entre admissões hospitalares de mulheres jovens com diagnóstico de esquizofrenia e as fases de seus ciclos menstruais, sugerindo uma correlação entre piora dos sintomas psicóticos e períodos de menor disponibilidade de estradiol.

Limitações desse estudo foram cuidadosamente apontadas, tais como a ausência de dosagens hormonais nas diversas fases do ciclo menstrual e a falta de dados precisos sobre quanto tempo antes da internação ocorreu a piora dos sintomas psicóticos - dados estes que poderiam ou não confirmar a hipótese de exacerbação dos sintomas psicóticos durante o período de relativo hipoestrogenismo.

O papel modulador dos estrógenos sobre os diversos neurotransmissores é extenso e bem documentado. ${ }^{2}$ Sua ação sobre o sistema dopaminérgico, de maior interesse nos quadros psicóticos, é particularmente complexa. Estudos com animais demonstraram ações inibitórias e facilitadoras, dependendo das dosagens e preparações de estrógenos empregadas, bem como do tempo de sua administração. Esse "efeito bifásico" se justifica por uma redução inicial da atividade dopaminérgica, seguida de mecanismo compensatório ("up regulation”) dos receptores pós-sinápticos. A ação dos estrógenos sobre neurônios dopaminérgicos se dá possivelmente por três mecanismos diferentes: intracelular (através da ligação com receptores esteróides); extracelular (ligando-se a receptores de membrana e, conseqüentemente, alterando sua estereoespecificidade); de forma indireta, interagindo com receptores serotonérgicos $5 \mathrm{HT}_{2}$, estes últimos gerando uma ação antagonista dopaminérgica. Desse modo é possível imaginar que, na prática clínica, o uso de estrógenos em diferentes formas (doses, via de administração e tempo de uso) resulte, conseqüentemente, em efeitos bem diversos sobre os comportamentos relacionados à atividade dopaminérgica.

Uma hipótese aventada por Bassit e Louzã Neto (e reforçada por trabalhos citados em sua introdução e discussão) merece maior discussão: a possível associação entre níveis reduzidos de estradiol e a piora de sintomas psicóticos e de humor - a chamada estrogen withdrawal theory. Embora inicialmente atraente, a hipótese de uma relação direta entre sintomatologia psíquica e níveis absolutos de estradiol tem sido recentemente contestada, através de desenhos experi- mentais mais cuidadosos. Trabalhos realizados pelo Behavioral Endocrinology Branch do NIMH, ${ }^{3,4}$ utilizando como modelos os distúrbios de humor pré-menstruais e puerperais, enfatizam a provável existência de subpopulações de mulheres que desenvolvem uma resposta anormal às flutuações hormonais consideradas normais para estes períodos. Em outras palavras, a variabilidade hormonal de determinados períodos do ciclo reprodutivo feminino funcionaria como um "gatilho" para estes subgrupos, independentemente dos níveis absolutos de seus hormônios gonadais.

Seria interessante examinar, dentre as pacientes investigadas por Bassit e Louzã Neto que apresentaram admissão hospitalar em períodos de relativo hipoestrogenismo, a existência (passada e/ou futura) de alterações de humor pré-menstruais, puerperais ou durante a transição para a menopausa. Esta população, certamente de maior risco, mereceria uma atenção cuidadosa durante períodos de maior instabilidade hormonal, inclusive com a possibilidade de intervenções hormonais de caráter preventivo.

Cláudio N Soares*
Center for Women's Mental Health
Perinatal and Reproductive Psychiatry Clinical
Research Program
Massachusetts General Hospital, Harvard Medical School,
Boston, USA
Perinatal and Reproductive Psychiatry Clinical
Research Program
Massachusetts General Hospital, Harvard Medical School
15 Parkman Street WACC 812 Boston, MA 02114, USA
E-mail: csoares@ @artners.org

\section{Referências}

1. Bassit DP, Louzã Neto MR. Relação entre data de admissão hospitalar e período do ciclo menstrual de mulheres com diagnóstico de esquizofrenia. Rev Bras Psiquiatr 2000;22:57-61.

2. DeBattista C, Smith DL, Schatzberg AF. Modulation of monoamine neurotransmitters by estrogen: clinical implications. In: Leibenluft E, editor. Gender differences in mood and anxiety disorders. Washington (DC): American Psychiatric Press; 1999. p. 137-60.

3. Schmidt PJ, Nieman LK, Danaceau MA, Adams LF, Rubinow DR. Differential behavioral effects of gonadal steroids in women with and in those without premenstrual syndrome. N Engl J Med 1998;338:209-16.

4. Bloch M, Schmidt PJ, Danaceau M, Murphy J, Nieman L, Rubinow DR. Effects of gonadal steroids in women with a history of postpartum depression. Am J Psychiatry 2000;157:924-30. 
Resposta:

O colega Soares descreve o complexo efeito do estradiol no sistema dopaminérgico, com ação inibitória ou excitatória dependendo da dose empregada. Cita também estudos do National Institute of Mental Health (NIMH) demonstrando que a variação dos níveis hormonais desencadeia alterações de humor em subgrupos específicos de mulheres e destaca que a relação direta entre níveis absolutos de estradiol e sintomatologia psíquica tem sido contestada. No entanto, um grupo da Austrália ${ }^{1}$ observou incremento na redução de sintomas positivos e negativos com a adição de $50 \mathrm{mcg}$ ou $100 \mathrm{mcg}$ de estradiol ao tratamento padrão de pacientes com esquizofrenia, sugerindo que o estradiol teria ação benéfica no tratamento de sintomas psicóticos em mulheres com esquizofrenia como um todo. É possível que as pacientes com variações de humor ao longo do ciclo tenham maior resposta à terapêutica hormonal, mas não se pode excluir uma relação específica dos sintomas psicóticos com níveis hormonais absolutos. Estes mesmos pesquisadores estão realizando estudos para procurar um marcador da piora dos sintomas psicóticos em pacientes com esquizofrenia nos períodos de hipoestrogenismo. ${ }^{2}$

Por fim, Soares sugere que seja investigada a presença de alterações de humor nos períodos em que há flutuação hormonal nas pacientes que foram internadas em período de relativo hipoestrogenismo, pois esta população teria maior risco de recaída nos períodos de maior instabilidade hormonal e poderia se beneficiar de intervenções hormonais com caráter preventivo. Tal investigação seria interessante para verificar se há correlação entre as alterações de humor e a piora dos sintomas psicóticos. Uma correlação positiva entre alterações do humor e piora de sintomas psicóticos associada ao hipoestrogenismo permitiria a adição de um recurso a mais no tratamento de pacientes com esquizofrenia, possivelmente ajudando a prevenir recaídas. É importante lembrar, no entanto, que o uso de estrógenos requer indicação e acompanhamento cuidadosos, devido a seus efeitos colaterais (como tromboembolismo e carcinomas hormônio-dependentes).

Débora P Bassitt e Mário R Louzã Neto

Projeto Esquizofrenia (Projesq) do Instituto de Psiquiatria do Hospital das Clínicas da Faculdade de Medicina da Universidade de São Paulo

Projesq - Instituto de Psiquiatria da Faculdade de Medicina da Universidade de São Paulo Av. Prof. Ovídio Pires de Campos, s/n ${ }^{\circ}$ 05403-010 São Paulo, SP, Brasil E-mail:dbassit@amcham.com.br

\section{Referências}

1. Kulkarni J, Riedel A, de Castella RA, Fitzgerald PB, Rolfe TJ, Taffe J, et al. Estrogen - A potential treatment for schizophrenia? In: Abstracts of the tenth biennial winter workshop on schizophrenia; 2000 Feb 5-11; Davos, Switzerland. Schiz Bull 2000;41:28.

2. de Castella RA, Silberstein RBJ, Kulkarni J. Background and methodology for a study exploring the relationship between psychopathology, sex esteroids and the EEG over the menstrual cycle in women with schizophrenia. In: Abstracts of the tenth biennial winter workshop on schizophrenia; 2000 Feb 5-11; Davos, Switzerland. Schiz Bull 2000;41:153.

\section{The safety of fluoxetine overdose: a case report}

\section{Introduction}

A crucial point in the choice of antidepressants is their safety in overdose. A retrospective epidemiological review ${ }^{1}$ showed that the overall rate of deaths per million of tricyclic antidepressants prescriptions was $34.14-13.48$ for monoamine oxidase inhibitors (MAOI), 6.19 for atypical drugs and 2.02 for selective serotonin reuptake inhibitors (SSRI). Tricyclic drug overdoses produce confusion, convulsions, hypotension, tachycardia, conduction delays and anticholinergic blockade manifestations. Patients may progress to coma, and cardiac arrhythmia may lead to death. The use of newer and more specific antidepressants may contribute to the safety in the treatment of suicidal patients. ${ }^{2}$

\section{Case report}

A 24 year-old female patient with major depression was admitted to the emergency room 9 hours after an ingestion of 2,800 $\mathrm{mg}$ of fluoxetine. This is a university service, part of the medical school and residence program. The patient was confused, with nausea and intense epigastric pain. Her electrocardiogram (EKG) showed an accelerated rhythm without any other abnormalities. She stayed in for clinical observation, with EKG monitoring and receiving intravenous (IV) fluids for 36 hours. 24 hours after the admission she was no longer confused. Gait instability was still present at that time, persisting for 72 hours after the overdose. Liver and renal function tests were within normal limits. She was treated with intensive dynamic psychotherapy for 3 weeks (antidepressant medications had been discontinued on admission, $40 \mathrm{mg} /$ day has been prescribed before the overdose). As the patient remained depressed, $40 \mathrm{mg} /$ day of fluoxetine were reintroduced under supervision. Depression remitted after 3 weeks of fluoxetine. After that, a psychiatrist followed up the patient for a year and then the medication was discontinued. She continued to receive psychodinamically-oriented therapy for a year more, showing complete remission.

\section{Discussion}

Suicide is a common event related to psychiatric disorders. Depression disorder is strongly associated with suicide, $30 \%$ to $70 \%$ of suicidal patients have this diagnostic. ${ }^{3}$ Antidepressants use must be carefully prescribed to these patients, taking into account the safety at overdose.

The report illustrates the safety of fluoxetine on massive overdose. Some authors describe fluoxetine safety at overdose, if used alone, ${ }^{4}$ but others report death when fluoxetine is used alone. ${ }^{5}$

Heterocyclic antidepressants and MAOIs have significant antidepressant effects but are particularly unsafe on drug overdoses. This observation must be taken into account when choosing antidepressant drugs for severely depressed patients with significant suicidal risk.

A single case report is an useful tool to understand rare events. But no further conclusions can be drawn from limited 
information. In this case, the fluoxetine safety prevented the patient death but there was a need for hospitalization. Suicidal depressed patients must be under intensive care by their psychiatrists; the antidepressant choice plays a fundamental role, but is only part of the whole treatment.

Marcelo F. Mello Departamento de Psiquiatria e Psicologia Médica da Unifesp/EPM

Hospital do Servidor Público Estadual

R. Jorge Coelho, 157 apt. 21 01451-020 São Paulo, SP, Brasil

\section{References}

1. Henry JA, Sener EK, Alexander CA. Relative mortality from overdose of antidepressants. BMJ 1995;310(6974):221-4.

2. Rudolph RL, Derivan AT. The safety and tolerability of venlafaxine hydrochloride: analysis of the clinical trial database. J Clin Psychopharmacol 1996;16(3 Suppl 2):54S-59S; discussion 59S-61S.

3. Goodwin FK, Runk BL. Suicide intervention: integration of psychosocial, clinical, and biomedical traditions. In: Jakobs D, editor. Suicide and clinical practice. Washington (DC): American Psychiatric Press; 1992.

4. Barbey JT, Roose SP. SSRI safety in overdose. J Clin Psychiatry 1998;59(Suppl 15):42-8.

5. Kincaid RL, McMullin MM, Crookham SB, Rieders F. Report of a fluoxetine fatality. J Anal Toxicol 1990;14(5):327-9. 